\title{
A case report of atypical Kawasaki disease presented with severe elevated transaminases and literature review
}

\author{
Yifan Ren ${ }^{*}$, Chuanxin Zhang, Xiaoqin Xu and Yu Yin
}

\begin{abstract}
Background: Kawasaki disease (KD) is the most common cause of acquired heart disease among children in developed countries, in which the resulting coronary artery (CA) abnormalities cause myocardial ischemia, infarction, and death. Prompt diagnosis was essential, and supplemental information should be used to assist the diagnosis when classical clinical criteria are incomplete. The elevated levels of serum transaminases in most KD patients are mild. Herein, a case of atypical KD child with severely elevated transaminase was reported.

Case presentation: A child with clinical manifestations of fever, high C-reactive protein (CRP) and severely elevated transaminases was reported. The treatment effect of antibiotic and liver-protecting drugs was not satisfactory. A bilateral diffuse dilation of the CA was detected on echocardiography on day 5 of the illness; thus, atypical KD was diagnosed. Elevated transaminases declined rapidly to normal after the treatment of intravenous immunoglobulin (IVIG). A 1-month follow-up revealed that CA returned to normal, and 2-month, 6-months, and 1-year follow-up revealed the child was in good general health.
\end{abstract}

Conclusions: This case highlighted that atypical KD clinical symptoms were diverse, and severely elevated transaminases might provide a clue to healthcare providers for the diagnosis and management of atypical KD.

Keywords: Atypical Kawasaki disease, Kawasaki disease, Severely elevated transaminases, Children, Case report

\section{Background}

Kawasaki disease (KD) is an acute vasculitis, which commonly affects children between the age of 6 months and 5 years. Although the precise cause of the disease is yet unknown, a common pathway in many infectious or environmental factors that trigger inflammation of the blood vessels in individuals with a genetic predisposition to this disease could be ascribed as the putative factors [1]. Elevated serum liver enzymes constituted the typical laboratory tests manifested in the gastrointestinal tract of KD [2]. However, severely elevated transaminases

\footnotetext{
*Correspondence: renyifan1213@163.com Department of Paediatrics, ShaoXing KeQiao Women And Children's Hospital, ShaoXing 312030, Zhejiang Province, PR China
}

could not be differentiated from atypical KD and infectious diseases, thereby delaying treatment.

\section{Case presentation}

A 1-year-old Han nationality boy was admitted to the Department of Pediatrics, Shaoxing Keqiao Women and Children's Hospital, Shaoxing, China, due to complaints of fever and cough occasionally for 2 days in March 2019. However, he did not experience breathing difficulty, chills, vomiting, diarrhea, yellowing of skin, convulsions, and rash. Also, the patient had no history of medication except for two $3-\mathrm{mL}$ ibuprofen suspensions. He had always been in good health, and no abnormal findings were detected at birth and in family history. Laboratory findings were as follows: blood routine examination: White blood

(c) The Author(s). 2021 Open Access This article is licensed under a Creative Commons Attribution 4.0 International License, which permits use, sharing, adaptation, distribution and reproduction in any medium or format, as long as you give appropriate credit to the original author(s) and the source, provide a link to the Creative Commons licence, and indicate if changes were made. The images or other third party material in this article are included in the article's Creative Commons licence, unless indicated otherwise in a credit line to the material. If material is not included in the article's Creative Commons licence and your intended use is not permitted by statutory regulation or exceeds the permitted use, you will need to obtain permission directly from the copyright holder. To view a copy of this licence, visit http://creativecommons.org/licenses/by/4.0/ The Creative Commons Public Domain Dedication waiver (http://creativecommons.org/publicdomain/zero/1.0/) applies to the data made available in this article, unless otherwise stated in a credit line to the data. 
cell count (WBC): $8.5(4-10) \times 10^{9} / \mathrm{L}$, percentage of neutrophils (N\%): $65.5 \quad(40-75)$, percentage of lymphocyte (L\%): 22.8 (40-60), hemoglobin (Hb): 100 $(110-150) \mathrm{g} / \mathrm{L}$, platelets (PLT): $240(100-300) \times 10^{9} /$ $\mathrm{L})$, C-reactive protein (CRP): $130.9(0-8) \mathrm{mg} / \mathrm{L}$. The other test results were as follows: erythrocyte sedimentation rate (ESR): $55(0-15) \mathrm{mm} / \mathrm{h}$, serum alanine aminotransferase (ALT): 1327 (9-50) U/L, aspartate aminotransferase (AST): 1584 (15-40) U/L, total bilirubin: $7.81(3.42-20.5) \mu \mathrm{mol} / \mathrm{L}$, direct bilirubin: 2.60 $(0.0-6.84) \quad \mu \mathrm{mol} / \mathrm{L}$, gamma glutamyl transferase (GGT): $248.9 \quad(10.0-60.0) \quad \mathrm{U} / \mathrm{L}$, and albumin 41.8 $(38.0-55.0) \mathrm{g} / \mathrm{L}$. Urinalysis revealed the presence of pyuria. The nitrite test was negative. Serological tests for hepatitis A, B, C, D, E, F, Epstein-Barr virus $(\mathrm{EBV})$, cytomegalovirus, and viruses in the respiratory tract were negative for acute infections. Abdominal ultrasonography showed normal liver, gallbladder, bile ducts, and pancreas. Chest radiographs suggested normal. Ceftriaxone $(80 \mathrm{mg} / \mathrm{kg} . \mathrm{d}$, qd) was intravenously injected to intervene the possible lung or urinary tract infection. Compound glycyrrhizin injection $20 \mathrm{~mL}(2$ $\mathrm{mL} / \mathrm{kg}, \mathrm{qd})$ and reduced glutathione $0.3 \mathrm{~g}(30 \mathrm{mg} / \mathrm{kg}$, qd) were administered to protect the liver. On day 4 post-hospitalization, a large red rash appeared on the chest and back of the child. The results of blood, urine, and throat cultures were negative, respectively, but the fever persisted despite intravenous administration of ceftriaxone for 3 days. The common cause of severely elevated transaminase in children is a viral infection, such as hepatitis A, B, C, D, E, F, EBV, and cytomegalovirus. Since the results for the above tests were negative for the child, and CRP was abnormally elevated, these were deemed incompatible with virus infection and attributed to bacterial infections, such as acute purulent cholecystitis that can cause elevated transaminases. Nonetheless, the child did not show any relevant clinical symptoms. Abdominal ultrasonography was normal, and ceftriaxone had poor antiinfective treatment effect, which further did not support the presence of bacterial infection. Bilateral diffuse dilatation of the CA $(2.6 \mathrm{~mm}$ left and $3.1 \mathrm{~mm}$ right), especially the right, was detected on echocardiography on day 5 post-hospitalization (Fig. 1). The Zscores of the left and right main coronary artery (CA) were 2.13 and 4.13, respectively. According to Z-score classification [2], the patient had a small CA aneurysm. In summary, the child with fever $\geq 5$ days, CRP $130.9 \mathrm{mg} / \mathrm{L}$, ESR $55 \mathrm{~mm} / \mathrm{h}, \mathrm{Hb} 100 \mathrm{~g} / \mathrm{L}$, elevated ALT level, urine $\geq 10 \mathrm{WBC} / \mathrm{hpf}$, CA aneurysm, fulfilled the diagnostic criteria of atypical KD [2]. Ectasia was frequently detected in the atypical KD than typical KD [3]. Thus, he was diagnosed as atypical KD and treated with aspirin $(35 \mathrm{mg} / \mathrm{kg} /$ day from days $5-8$ of hospitalization and $4.5 \mathrm{mg} / \mathrm{kg} / \mathrm{day}$ from day 9 of hospitalization for the following 3 months) and Intravenous immunoglobulin (IVIG) $(2 \mathrm{~g} / \mathrm{kg} /$ day) for $10 \mathrm{~h}$ on day 5 of hospitalization. Ceftriaxone was stopped

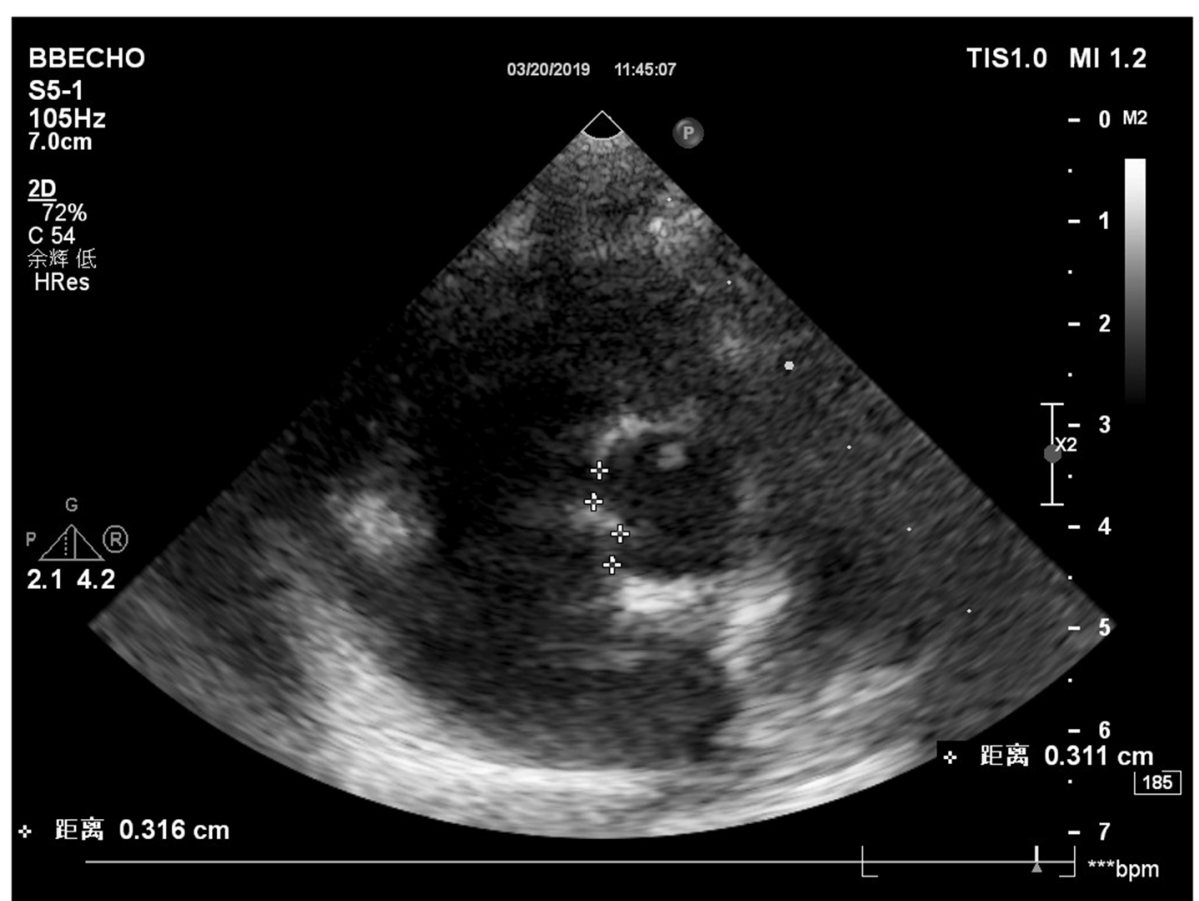

Fig. 1 Right CA aneurysm $(3.1 \mathrm{~mm})$ was detected on echocardiography on day 5 of hospitalization 


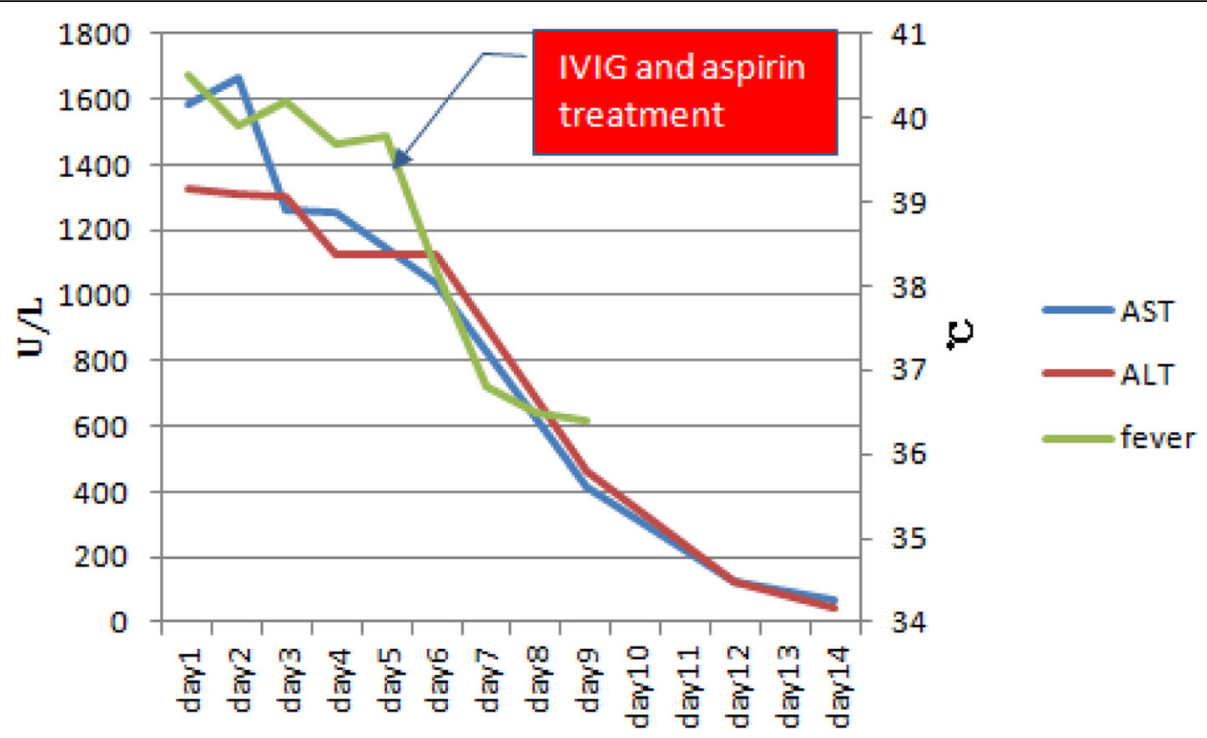

Fig. 2 Trends of transaminases and temperature of the patient during hospitalization

on day 5 of hospitalization. After $24 \mathrm{~h}$ of treatment, clinical and laboratory parameters improved rapidly with regression of fever and aminotransferase levels on day 6 post-hospitalization. The trends of temperature and elevated transaminases are shown in Fig. 2. The child was discharged on day 9 of hospitalization. Also, a gradual regression was observed in the coronary blood vessels when normalized to the echocardiographic findings after 1 month (Fig. 3). Moreover, 2-months, 6-months, and 1- year follow-up did not show any recurrence of fever or an additional increase in the CA diameters corresponding to the maintenance dose $(4.5 \mathrm{mg} / \mathrm{kg} /$ day for 3 months $)$ of aspirin.

\section{Discussion}

According to literature, elevated serum transaminases or gamma glutamyl transpeptidase is observed in $40-60 \% \mathrm{KD}$ patients [4]. The majority of the patients show only a mild

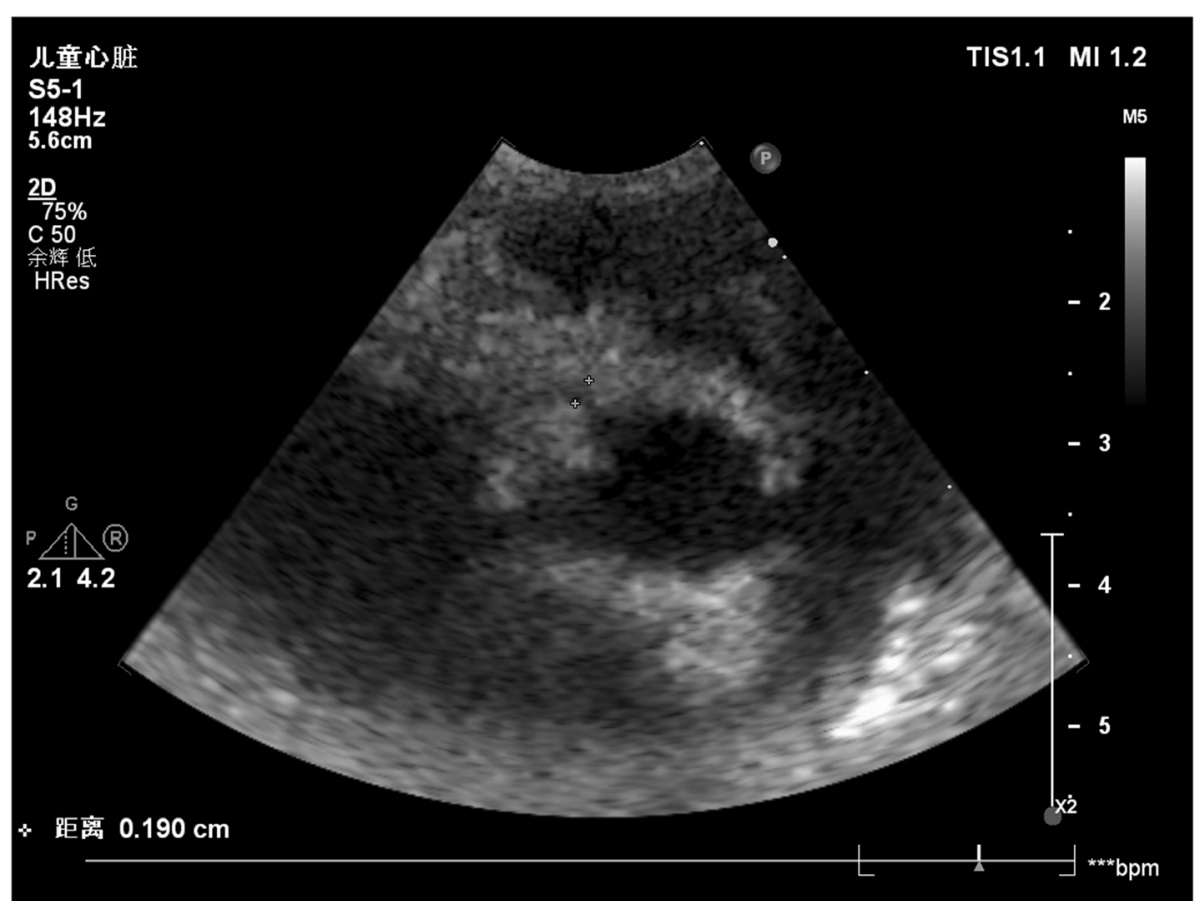

Fig. 3 A gradual regression was observed in the CA aneurysm on echocardiography after 1 month 
increase in transaminases, which is $<2$-fold of the upper limit of normal, and only a few patients showed 10-fold of the upper limit of the normal (Table 1) [9]. Although severely elevated transaminase is rare, it could mislead the diagnosis and delay the treatment. Reportedly, high ALT and GGT values in the acute phase are related to IVIG resistance [4]. However, this phenomenon was not observed in our case. The main purpose of this case report was to acquaint the pediatricians that atypical KD may have masqueraded in various guises, and hence, the variability of this disease should not be ignored. To minimize the diagnostic delay, we investigated the clinical manifestations of atypical KD (Table 1).

Since the cause of KD was unknown, it was speculated to be associated with the region, year, gender, season, family history, and genetics. Accumulating evidence linked KD to tropospheric wind patterns, which suggested that the transport of an agent when inhaled by genetically susceptible children, triggers the immunological cascade of KD [2]. In addition to CA abnormalities, hepatic dysfunction is also a common complication during the acute KD episode. Reportedly, $90.95 \%$ of $\mathrm{KD}$ patients have at least 1 abnormal liver function test, wherein hypoalbuminemia is the most prevalent type, followed by elevated AST, low total protein, low albumin/globulin ratio, and hyperbilirubinemia; however, the contributing factors are yet unclear and could be associated with inflammatory mediators, infectious agents, therapy, or a combination of the above [10]. Fei et al. reported continuous veno-venous hemodiafiltration that could rapidly reduce the levels of interleukin-6 (IL-6) and tumor necrosis factor-alpha (TNF- $\alpha$ ) and improve the organ function of KD complicated with multiple organ dysfunction syndromes [11]. This concept provided a rescue therapy in children with KD complicated with severe organ damage. Intriguingly, Sundel et al. suggested a process initiated by an innate immune response to explain the pathophysiology of $\mathrm{KD}$. It involved a reaction mediated by the acquired immune system, resulting in the loss of blood vessel structural integrity, arterial wall dilatation, and aneurysm formation [12]. Fei and Sundel proposed that the immune response was involved in the pathogenesis of $\mathrm{KD}$ $[11,12]$. Severely elevated transaminases of atypical KD might be related to severe immune damage to the liver.

Hua et al. reported that in patients $\leq 6$-months-old, total fever duration of $\geq 8$ days, delayed diagnosis, and albumin (ALB) $\leq 35.9 \mathrm{~g} / \mathrm{L}$ were independent risk factors for acute and subacute KD combined with CA lesions (CAL) [13]. Shi et al. reported that delayed hospitalization is one of the factors of the increased risk of CAL in patients with atypical KD [14]. Yunjia et al. demonstrated that patients aged $\leq 1$ year-old receive IVIG treatment after day 10 of illness, and IVIG non-responders were associated with the regression in persistent CA aneurysms (CAA) [15]. In summary, timely admission to the hospital and prompt treatment for KD patients is essential. Therefore, early recognition of the clinical symptoms of atypical KD, such as severe liver damage, is vital for the treatment of the disease.

\section{Conclusion}

KD could lead to severe complications, such as CAAs and thromboembolic occlusions. Thus, early diagnosis of the disease is an urgent requirement. Atypical KD clinical symptoms are diverse. Severely elevated transaminases could be one of the manifestations of atypical KD.

Table 1 Case reports of atypical KD

\begin{tabular}{|c|c|c|c|c|c|c|c|}
\hline $\begin{array}{l}\text { Case } \\
\text { source }\end{array}$ & Gender & $\begin{array}{l}\text { Age } \\
\text { (year) }\end{array}$ & Clinical manifestations & AST & ALT & Treatment & Prognosis \\
\hline $\begin{array}{l}\text { Turkey } \\
\text { [5] }\end{array}$ & boy & 6 & $\begin{array}{l}\text { fever, abdominal pain, jaundice, desquamation of fingers, bilateral } \\
\text { conjunctival erythema }\end{array}$ & $\begin{array}{l}29 \mathrm{U} / \\
\mathrm{L}\end{array}$ & $42 \mathrm{U} / \mathrm{L}$ & $\begin{array}{l}\text { IVIG acetylsalicylic } \\
\text { acid (ASA) }\end{array}$ & recovery \\
\hline $\begin{array}{l}\text { Turkey } \\
{[5]}\end{array}$ & boy & 2.5 & $\begin{array}{l}\text { fever, swelling, redness of upper surface of foot, cholestasis, and } \\
\text { bilateral conjunctival erythema }\end{array}$ & $\begin{array}{l}44 \mathrm{U} / \\
\mathrm{L}\end{array}$ & $51 \mathrm{U} / \mathrm{L}$ & $\begin{array}{l}\text { IVIG } \\
\text { ASA }\end{array}$ & $\begin{array}{l}\text { good } \\
\text { general } \\
\text { health }\end{array}$ \\
\hline Iran [6] & boy & 1.3 & $\begin{array}{l}\text { fever, bilateral bulbar, non-purulent conjunctivitis, unilateral cervical } \\
\text { lymphadenopathy, erythematous oral and pharyngeal mucosa }\end{array}$ & $\begin{array}{l}351 \\
U / L\end{array}$ & $40 \mathrm{U} / \mathrm{L}$ & $\begin{array}{l}\text { IVIG } \\
\text { aspirin }\end{array}$ & $\begin{array}{l}\text { good } \\
\text { general } \\
\text { health }\end{array}$ \\
\hline $\begin{array}{l}\text { New } \\
\text { York } \\
{[7]}\end{array}$ & boy & 5 & $\begin{array}{l}\text { fever, emesis, right upper quadrant, abdominal pain, scleral icterus, } \\
\text { bilateral nonexudative conjunctivitis, and inguinal rash with pealing }\end{array}$ & $1.25 \mu \mathrm{kat} /$ & $\begin{array}{l}3.31 \\
\mu \mathrm{kat} / L\end{array}$ & $\begin{array}{l}\text { IVIG } \\
\text { aspirin }\end{array}$ & recovery \\
\hline $\begin{array}{l}\text { New } \\
\text { York } \\
{[7]}\end{array}$ & girl & 4 & $\begin{array}{l}\text { fever, Jaundice, abdominal pain, itchy rash on the arms and legs, } \\
\text { maculopapular rash red, cracked lips, a red tongue, and peeling skin } \\
\text { in the groin and on the hands }\end{array}$ & $0.9 \mu \mathrm{kat} /$ & $1.35 \mu k a t /$ & $\begin{array}{l}\text { IVIG } \\
\text { aspirin }\end{array}$ & recovery \\
\hline $\begin{array}{l}\text { New } \\
\text { York } \\
{[8]}\end{array}$ & boy & 2.5 & $\begin{array}{l}\text { fever, bilateral non-suppurative conjunctivitis, right upper quadrant } \\
\text { tenderness, gallbladder hydrops persistent, abnormal liver function } \\
\text { tests }\end{array}$ & $\begin{array}{l}115 \\
U / L\end{array}$ & $146 \mathrm{U} / \mathrm{L}$ & $\begin{array}{l}\text { IVIG } \\
\text { ursodeoxycholic } \\
\text { acid, intravenous } \\
\text { antibiotics }\end{array}$ & $\begin{array}{l}\text { good } \\
\text { general } \\
\text { health }\end{array}$ \\
\hline China & boy & 1 & fever, rash, bilateral diffuse dilatation of CA & $\begin{array}{l}1584 \\
U / L\end{array}$ & $1327 \mathrm{U} / \mathrm{L}$ & $\begin{array}{l}\text { IVIG } \\
\text { aspirin }\end{array}$ & recovery \\
\hline
\end{tabular}




\section{Abbreviations}

KD: Kawasaki disease; CA: Coronary artery; CRP: C-reactive protein; IVIG: Intravenous immunoglobulin; WBC: White blood cell count; N\%: Percentage of neutrophils; L\%: Percentage of lymphocyte; Hb: Hemoglobin; PLT: Platelets; ESR: Erythrocyte sedimentation rate; ALT : Serum alanine aminotransferase; AST: Aspartate aminotransferase; GGT: Gamma glutamyl transferase; EBV: Epstein-Barr virus; IL-6: Interleukin-6; TNF-a: Tumor necrosis factor-alpha; ALB: Albumin; CAL: Coronary artery lesions; CAA: Coronary artery aneurysms

\section{Acknowledgments}

This study was partially supported by the Department of Pulmonology, The Children's Hospital, Zhejiang University School of Medicine.

\section{Authors' contributions}

YFR collected the data, reviewed literature, drafted the manuscript, and read and approved the final manuscript. CXZ, XQX, and YY helped with the literature review and data collection. All authors read and approved the manuscript.

\section{Funding}

Not applicable.

\section{Availability of data and materials}

All data generated or analyzed during this study are included in the article.

\section{Declarations}

Ethics approval and consent to participate

This study was approved by the Research Ethics Committee of Children's Hospital, College of Medicine, Zhejiang University.

\section{Consent for publication}

Written informed consent was obtained from the patient's parents for publication of this case report and any accompanying images. A copy of the written consent is available for review.

\section{Competing interests}

The authors declare that they have no competing interests.

Received: 15 October 2020 Accepted: 21 April 2021

Published online: 04 May 2021

\section{References}

1. Moreno MA. Summarizing what has been learned about Kawasaki disease. JAMA Pediatr. 2016;170(11):1124. https://doi.org/10.1001/jamapediatrics.201 5.2568 .

2. McCrindle BW, Rowley AH, Newburger JW, Burns JC, Bolger AF, Gewitz M, et al. Diagnosis, treatment, and long-term Management of Kawasaki Disease: a scientific statement for health professionals from the American Heart Association. Circulation. 2017;135(17):e927-99. https://doi.org/10.1161/ CIR.0000000000000484.

3. Behmadi M, Alizadeh B, Malek A. Comparison of clinical symptoms and cardiac lesions in children with typical and atypical kawasaki disease. Med Sci (Basel). 2019;7(4):63.

4. Tremoulet AH, Jain S, Chandrasekar D, Sun X, Sato Y, Burns JC. Evolution of laboratory values in patients with Kawasaki disease. Pediatr Infect Dis J. 2011;30(12):1022-6. https://doi.org/10.1097/INF.0b013e31822d4f56.

5. Kaman A, Aydın-Teke T, Gayretli-Aydın ZG, Öz FN, Metin-Akcan Ö, Eriş D, et al. Two cases of Kawasaki disease presented with acute febrile jaundice. Turk J Pediatr. 2017:59(1):84-6. https://doi.org/10.24953/turkjped.2017.01.015.

6. Rohani P, Imanzadeh F, Sayyari A, Kazemi AM, Shiari R. Persistent elevation of aspartate aminotransferase in a child after incomplete Kawasaki disease: a case report and literature review. BMC Pediatr. 2020;20(1):73. https://doi. org/10.1186/s12887-020-1975-8.

7. Majumdar I, Wagner S. Kawasaki disease masquerading as hepatitis: a diagnostic challenge for pediatricians. Clin Pediatr (Phila). 2016;55(1):73-5. https://doi.org/10.1177/0009922815569206.

8. Rosencrantz RA, Huang T, Sonke PY, Tewari D, Chander PN. Autoimmune sclerosing cholangitis: an atypical association with Kawasaki disease. Hepatology. 2016;64(6):2253-6. https://doi.org/10.1002/hep.28694.
9. Eladawy M, Dominguez SR, Anderson MS, Glodé MP. Abnormal liver panel in acute Kawasaki disease. Pediatr Infect Dis J. 2011;30(2):141-4. https://doi. org/10.1097/INF.0b013e3181f6fe2a.

10. Mammadov G, Liu HH, Chen WX, Fan GZ, Li RX, Liu FF, et al. Hepatic dysfunction secondary to Kawasaki disease: characteristics, etiology and predictive role in coronary artery abnormalities. Clin Exp Med. 2020;20(1): 21-30. https://doi.org/10.1007/s10238-019-00596-1.

11. Wang F, Cui Y, Wang CX, Xiao TT, Chen RX, Zhang YC. Effects of continuous veno-venous hemodiafiltration in patients with severe Kawasaki disease complicated with multiple organ dysfunction syndrome. Zhonghua Er Ke Za Zhi. 2018;56(9):691-4. https://doi.org/10.3760/cma.j.jssn.0578-1310.2018.09. 011.

12. Sundel RP. Kawasaki disease. Rheum Dis Clin N Am. 2015;41(1):63-73, viii. https://doi.org/10.1016/j.rdc.2014.09.010.

13. Hua W, Ma F, Wang Y, Fu S, Wang W, Xie C, et al. A new scoring system to predict Kawasaki disease with coronary artery lesions. Clin Rheumatol. 2019; 38(4):1099-107. https://doi.org/10.1007/s10067-018-4393-7.

14. Shi H, Qiu H, Jin Z, Li C, Yang X, Huang C, et al. Coronary artery lesion risk and mediating mechanism in children with complete and incomplete Kawasaki disease. J Investig Med. 2019;67(6):950-6. https://doi.org/10.1136/ jim-2018-000898.

15. Tang $Y$, Yan $W$, Sun L, Xu Q, Ding $Y, L v ~ H$. Coronary artery aneurysm regression after Kawasaki disease and associated risk factors: a 3-year followup study in East China. Clin Rheumatol. 2018;37(7):1945-51. https://doi.org/1 0.1007/s10067-018-3977-6.

\section{Publisher's Note}

Springer Nature remains neutral with regard to jurisdictional claims in published maps and institutional affiliations.
Ready to submit your research? Choose BMC and benefit from:

- fast, convenient online submission

- thorough peer review by experienced researchers in your field

- rapid publication on acceptance

- support for research data, including large and complex data types

- gold Open Access which fosters wider collaboration and increased citations

- maximum visibility for your research: over $100 \mathrm{M}$ website views per year

At BMC, research is always in progress.

Learn more biomedcentral.com/submissions 